\title{
Performance evaluation of a cabinet solar dryer for drying red pepper in Bangladesh
}

\author{
Muhammad Zakaria Hossain, ${ }^{1}$ Md Masud Alam, ${ }^{2}$ Md Faruq Bin Hossain, ${ }^{3}$ MSH Sarker, ${ }^{4}$ \\ Md Abdul Awal, ${ }^{5}$ Nusrat Jahan ${ }^{1}$ \\ ${ }^{1}$ Farm Machinery and Postharvest Process Engineering Division, Bangladesh Agricultural Research Institute, Gazipur; \\ ${ }^{2}$ Spices Research Centre, Bangladesh Agricultural Research Institute, Bogra; ${ }^{3}$ Hajee Mohammad Danesh Science and \\ Technology University (HSTU), Dinajpur; ${ }^{4}$ Postharvest Technology Division, Bangladesh Agricultural Research \\ Institute, Gazipur; ${ }^{5}$ Farm Power and Machinery, Bangladesh Agricultural University, Mymensingh, Bangladesh
}

\begin{abstract}
A cabinet type solar dryer was designed and fabricated over a collector and dryer area of $4.00 \mathrm{~m}^{2}$ and $7.5 \mathrm{~m}^{2}$ respectively for the geographical condition of Bangladesh. Red pepper was used to test the performance of the dryer. The upper tray and lower tray pepper drying needed 36 and $41 \mathrm{~h}$ to reduce moisture from $73 \%$ (wet basis) to $10 \%$ (wet basis) respectively and found $9 \mathrm{~kg}$ dried pepper from $30 \mathrm{~kg}$ fresh red ripe pepper. In contrast, open sun drying needed $85 \mathrm{~h}$ to reduce moisture from $73 \%$ (wet basis) to $11 \%$ (wet basis) and produced $2.43 \mathrm{~kg}$ dried pepper from $8 \mathrm{~kg}$ red ripe pepper. The average global radiation was about $133 \mathrm{~W} / \mathrm{m}^{2}$ while the flux incidence and flux absorbed on collector was about 128 $\mathrm{W} / \mathrm{m}^{2}$ and $103 \mathrm{~W} / \mathrm{m}^{2}$ respectively. The average collector and dryer efficiency was about $48 \%$ and $34 \%$ respectively. The average exergy efficiency was obtained $63 \%$. The average rate of top, bottom and side collector loss was $37 \mathrm{~W} / \mathrm{m}^{2}, 20 \mathrm{~W} / \mathrm{m}^{2}$ and $3 \mathrm{~W} / \mathrm{m}^{2}$ respectively. The upper tray, lower tray and open sun pepper seed germination was $76 \%, 81 \%$ and $85 \%$ respectively $(\mathrm{P} \geq 0.01)$. The
\end{abstract}

Correspondence: Muhammad Zakaria Hossain, Farm Machinery and Postharvest Process Engineering Division, Bangladesh Agricultural Research Institute, Gazipur, Bangladesh.

E-mail: zakariahossain@bari.gov.bd

Key words: Cabinet solar dryer; colour; energy; exergy; germination; pepper.

Acknowledgements: the authors are gratefully acknowledged to Spices Research Centre, Farm Machinery and Postharvest Process Engineering Division, Bangladesh Agricultural Research Institute (BARI) and Bangladesh Agricultural Research Council (BARC) and for their technical and financial support.

Received for publication: 16 August 2017.

Accepted for publication: 8 November 2017.

(C) Copyright M.Z. Hossain et al., 2018

Licensee PAGEPress, Italy

Journal of Agricultural Engineering 2018; XLIX:774

doi:10.4081/jae.2018.774

This article is distributed under the terms of the Creative Commons Attribution Noncommercial License (by-nc 4.0) which permits any noncommercial use, distribution, and reproduction in any medium, provided the original author(s) and source are credited. redness value of lower tray pepper $\left(a^{*}=27.1\right)$ was higher followed by upper tray $\left(a^{*}=24.7\right)$ and open sun pepper powder $\left(a^{*}=21.1\right)$, which means direct exposure of sunlight diminishes the quality of pepper colour. The redness value of fabricated solar drying was significantly $(\mathrm{P} \leq 0.01)$ higher than that of open sun drying.

\section{Introduction}

Solar energy is a cheap, clean and safe renewable energy source, which has been used in agricultural product drying since the dawn of civilisation. Solar drying is the oldest preservation technique of agricultural products using several types of solar crop dryers based mostly on solar energy, which is abundant, renewable and sustainable (Azaizia et al., 2017). With the development of modern science and technology, scientists all over the world augmented many research works to facilitate efficient use of solar energy for crop drying. Many assumptions were made for designing of collector, dryer chamber, number of trays and fan power etc. for different crop in different geographical location. All are purposed for maximising dryer efficiency, judicial use of energy and minimising energy loss especially in developing world where energy is a crisis and mechanical drying is not possible due to excessive initial investment (Muhlbauer et al., 1993).

Bangladesh (lat. 20.57 ${ }^{\circ}-26.63^{\circ} \mathrm{N}$ and long. 88.02 ${ }^{\circ}-92.68^{\circ} \mathrm{E}$ ) is a developing country, lies in a semi-tropical region, having annual solar radiation of $1700 \mathrm{kWh} / \mathrm{m}^{2}$. It has about $7.6 \mathrm{~h}$ of average bright day length in the dry season, while in monsoon it is nearly $5 \mathrm{~h}$ (Shakir et al., 2012). The amount of solar radiation and day length demonstrates potentiality of solar energy use for agricultural product drying in this territory. Nevertheless, the high amount of rainfall (average yearly $208 \mathrm{~mm}$ ) is a matter of concern especially in monsoon, as it becomes problem in drying, reducing quality of dried product, especially for open sun drying (World Bank, 2016).

Open sun drying is an ancient practice, which exhibits slow draying rate, dirt or fungal contamination in product, birds and rodents' attack and deterioration of quality, especially colour or flavour degradation (Hossain, 2003). But, still more than $90 \%$ of people practice this traditional sun drying method in Bangladesh. The main reason for such tendency is assumed as, lack of suitable dryer technology which can be adopted in this region and lack of quality concern among the farmers and consumers, which is believed to be replaced soon, as people are being conscious about food safety day by day.

Pepper is an important spice in Bangladesh, used at everyday 
meals either fresh or powdery. In consuming fresh pepper, no extra care is needed for processing etc. while, preparing pepper powder needs proper drying and crushing. Dried pepper is more popular in the subcontinent than other region of the world and the production is also higher in this region. Due to lack of proper dryer, farmer tends to sell green pepper in the local market although they get a very few profit. The main reason for such tendency is traditional sun drying practice is labour intensive and time consuming. Moreover if the dried product does not look attractive, they do not get the proper value of their product. In this case a suitable dryer is needed for the farmers so that they can produce quality-dried product, which will help them to be benefited economically, fulfilling national and international demand.

Hossain and Bala (2006) developed a mixed mode type forced convection solar tunnel dryer under the weather conditions of Bangladesh. The dryer consisted of transparent plastic covered flat-plate collector and a drying tunnel connected in series to supply hot air directly into the drying tunnel using two fans operated by a photovoltaic module. The dryer had a loading capacity of 80 $\mathrm{kg}$ of fresh peppers. Moisture content of red pepper was reduced from 2.85 to $0.05 \mathrm{~kg} / \mathrm{kg}(\mathrm{db})$ in $20 \mathrm{~h}$ in solar tunnel dryer and it took $32 \mathrm{~h}$ to reduce the moisture content to 0.09 and $0.40 \mathrm{~kg} / \mathrm{kg}$ (db) in improved and conventional sun drying methods, respectively. Chowdhury et al. (2011) presented an energy and exergy analysis of solar drying of jackfruit leather in a solar tunnel dryer. Jackfruit leather was dried from initial moisture content of about $76 \%$ (w.b.) to $12 \%$ moisture content (w.b.) in the solar tunnel dryer within 2 days of drying while at the same drying time the moisture content of similar sample reached $14 \%$ (w.b.) in the open sun drying method. Pangavhane et al. (2002) developed a natural convection solar dryer consisting of a solar air heater and a drying chamber for drying various agricultural products like fruits and vegetables and reported that shade drying and open sun drying required 15 and 7 days, respectively, while the natural convection solar dryer took only 4 days and produced better quality raisins. An indirect forced convection solar dryer integrated with different sensible heat storage maternal was developed and tested by Mohanraj and Chandrasekar (2009) for its performance for drying pepper under the metrological conditions of Pollachi, India. The system consists of a flat plate solar air heater with heat storage unit, a drying chamber and a centrifugal blower. Drying experiments was performed at an air flow rate of $0.25 \mathrm{~kg} / \mathrm{s}$. Drying of pepper in a forced convection solar dryer reduced the moisture content from around $72.8 \%$ (wet basis) to the final moisture content about $9.1 \%$ in $24 \mathrm{~h}$. The average dryer efficiency was estimated as about $21 \%$.

Though a significant amount of research was conducted on solar dryer at all over the world but a very few work was accomplished in the geographical condition of Bangladesh. Hossain and Bala (2006) developed a solar tunnel dryer at Bangladesh Agricultural University, Mymensingh and found technically suitable for drying red and green peppers. Hossain (2011) also developed a hybrid dryer at Bangladesh Agricultural Research Institute, Gazipur, which is run by solar energy as well as by electrical heater as a supplement energy source and found good for seed drying. Cabinet type solar dryer can be another option to be adopted in this region, thus the research was undertaken. The paper focuses on design, fabrication and energy utilisation character of cabinet solar dryer for the geographical condition of Bangladesh, especially Shibganj, Bogra $\left(25.1^{\circ} \mathrm{N}, 89.19^{\circ} \mathrm{E}\right)$ to dry red pepper.

\section{Materials and methods}

\section{Design consideration}

The cabinet solar dryer is consisted of two main parts namely dryer and collector. The dryer area is composed of drying chamber, four numbers of drying trays, exhaust pipe, exhaust fan and solar panel etc. The outer cover of the dryer is made by insulating materials such as poly-vinyl-chloride (PVC) sheet, which is also water resistive. The trays are placed in two columns where two trays are placed in each column. The trays are made from poly-coated iron net for better perforation and resistance to weather. To ensure easy movement, four number of bearing over a diameter of $10 \mathrm{~mm}$ was attached at the bottom of the each tray. The exhaust fan is attached to the end of the exhaust pipe placed vertically attached at the top end part of the dryer. The solar panel is attached just above the man height and beside of the dryer concerning that the panel shade does not fall on the top of the dryer. The main part of the collector is the absorber plate. The absorber plate is a corrugated iron sheet, which is painted by black colour for absorbing more solar energy. The collector and the solar panel are placed at a tilt angle of $23.5^{\circ}$, which is recommended for maximum exposure of solar radiation in the research location (Bala, 1998). The collector inlet and exhaust area is kept similar for smooth entry of air. For easy handling and movement 10 number of wheel over a diameter of $10 \mathrm{~cm}$ was fixed at he bottom of the dryer frame. The engineering drawing and prototype picture of the dryer is shown in Figure 1A-C.

The dryer was designed following the design parameter shown in Table 1 and equation 1 to 12 (Joshua, 2008):

$$
\begin{aligned}
& \text { Amount of moisture removed from product; } \\
& M_{r}=\frac{W_{p}\left(M_{i}-M_{f}\right)}{\left(100-M_{f}\right)}=21.85 \mathrm{~kg}
\end{aligned}
$$

Calculation of Energy; $\mathrm{E}=\mathrm{M}_{\mathrm{r}} \times \mathrm{L}=52434.78 \mathrm{~kJ}$

Collector area; $A_{c}=\frac{E}{S_{r} \times \eta}=4.00 \mathrm{~m}^{2}$

Length of the collector; $L_{c}=\frac{A_{c}}{w}=2.67 \mathrm{~m}$

Drying rate; $\mathrm{D}_{\mathrm{r}}=\frac{\mathrm{M}_{t}}{\mathrm{t}}=0.91 \mathrm{~kg} / \mathrm{h}$

Mass flow rate; $\mathrm{m}_{\mathrm{f}}=\frac{\mathrm{D}_{\mathrm{r}}}{\left(\mathrm{W}_{\mathrm{a} 2}-\mathrm{W}_{\mathrm{a} 1}\right) \times 3600}=0.13 \mathrm{~kg} / \mathrm{s}$

Volumetric air flow rate; $V_{a}=\frac{m_{f}}{\rho_{a}}=0.11 \mathrm{~m}^{3} / \mathrm{s}$

Outlet area; $\mathrm{O}_{\mathrm{a}}=\frac{\mathrm{v}_{\mathrm{a}}}{\mathrm{V}_{\mathrm{w}}}=0.03 \mathrm{~m}^{2}$

Outlet diameter; $\mathrm{D}_{\mathrm{o}}=\sqrt{\left\{\pi \times \mathrm{O}_{\mathrm{a}}\left(\mathrm{cm}^{2}\right)\right\} / 4}=15.86 \mathrm{~cm}$

Drying area; $A_{d}=\frac{w_{p}}{\rho_{s}}=7.5 \mathrm{~m}^{2}$

Considering number of tray, $\mathrm{N}_{\mathrm{t}}=4$ :

Area of each tray; $A_{t}=\frac{A_{d}}{N_{t}}=1.875 \mathrm{~m}^{2}$

Width of each tray; $W_{t}=\frac{A_{t}}{L_{t}}=1.25 \mathrm{~m}$ 


\section{Drawing of dryer in SolidWorks 2014}

SolidWorks is a computer aided drawing and simulation tool that supports users in creating precise drawing, solid models and many more. The SolidWorks part mode allows users to create parts, whereas its assembly mode supports the assembling of parts to create an assembly (Anonymous, 2016a). The solar dryer was drawn in SolidWorks 2014. The dimension unit was in millimetre. The value was inserted per calculation of the equation, from 8 to 12 .

\section{Dryer fabrication materials}

The specification of the dryer is shown in the Table 2.

\section{Drying of pepper}

About $30 \mathrm{~kg}$ and $8 \mathrm{~kg}$ of fresh harvested red ripe pepper of same variety (line CO517) was collected from the research field of Spices Research Centre, Shibgonj, Bogra for drying in the dryer and open sun respectively. The initial weight of pepper was weighed by an electric balance (MATP-31, China). The data of solar radiation, airflow rate, temperature, and relative humidity was recorded by solar meter (UVA 18573, USA), anemometer (TA 430, England), digital thermometer (K202, Germany) and hygrometer (GM 1360, China) respectively from 8:00 am to 5:00 p.m. at one-hour interval. Six samples were placed at different part of the top and bottom tray. These samples were weighed at one-hour interval by an electric balance (FA2004B, China) in order to calculate drying rate. Similarly, six samples were placed on the open sun and they were also weighed for every one-hour interval. The final weight of the pepper was recorded by the electric balance.

\section{Energy balance}

An energy balance on the absorber plate yields the following equation tor a steady state (Sukhatme, 1997):

$q_{u}=A_{p} S-q_{l}$

\section{Energy and exergy analysis}

The thermal efficiency of a solar collector is the ratio of useful heat gained to the solar radiation incident on the plane of the collector. This thermal efficiency is expressed as (Fudholi et al., 2013):

$$
\eta_{c}=\frac{m_{f} C\left(T_{o}-T_{i}\right)}{A_{c} I_{g}} \times 100 \%
$$

Moreover, system-drying efficiency is defined as the ratio of the energy required evaporating moisture to the heat supplied to the dryer. The system drying efficiency can be obtained using the

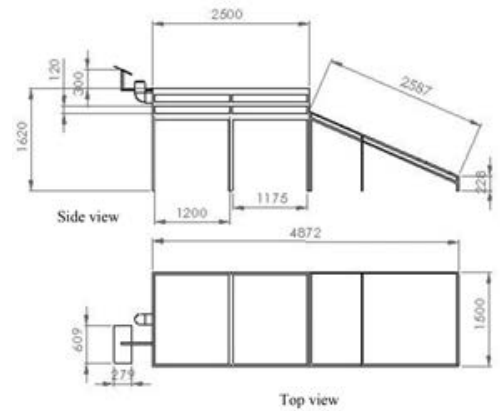

A
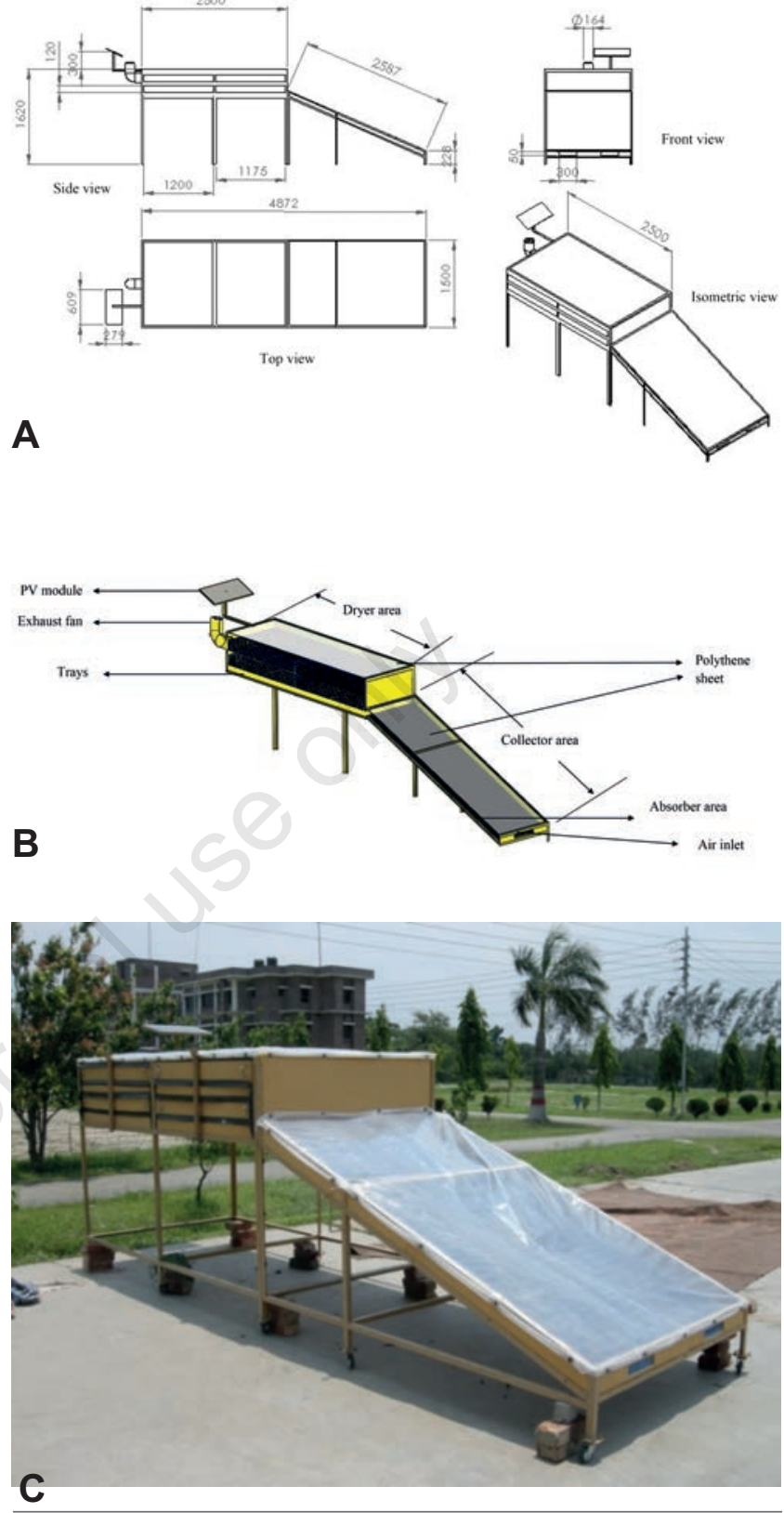

Figure 1. A) Engineering 2D drawing of the dryer in SolidWorks 2014 (values are in millimeter); B) cross-sectional 3D view of different parts of the dryer in SolidWorks 2014; C) prototype of the cabinet solar dryer.

Table 1. Design parameter of the dryer.

\begin{tabular}{llll}
\hline Sample weight $\left(\mathrm{W}_{\mathrm{p}}\right)$ & $30 \mathrm{~kg}$ & Air density on average $40^{\circ} \mathrm{C}$ drying temperature $\left(\rho_{\mathrm{a}}\right)$ & $1.127 \mathrm{~kg} / \mathrm{m}^{3}$ \\
Initial moisture $\left(\mathrm{M}_{\mathrm{i}}\right)$ & $75 \%$ & Wind speed $\left(\mathrm{V}_{\mathrm{w}}\right)$ & $3.5 \mathrm{~m} / \mathrm{s}$ \\
\hline Final moisture $\left(\mathrm{M}_{\mathrm{f}}\right)$ & $8 \%$ & Ambient temperature $\left(\mathrm{T}_{\mathrm{a}}\right)$ & $30^{\circ} \mathrm{C}$ \\
Latent heat $(\mathrm{L})$ & $2400 \mathrm{~kJ} / \mathrm{kg}$ & Dryer temperature $\left(\mathrm{T}_{\mathrm{d}}\right)$ & $50^{\circ} \mathrm{C}$ \\
\hline Solar insolation for three days drying $\left(\mathrm{S}_{\mathrm{r}}\right)$ & $52,380 \mathrm{~kJ} / \mathrm{m}^{2}$ & Drying time $(\mathrm{t})$ & $24 \mathrm{~h}$ \\
Dryer efficiency $(\eta)$ & $25 \%$ & Spreading density $\left(\rho_{\mathrm{s}}\right)$ & $4 \mathrm{~kg} / \mathrm{m}^{2}$ \\
\hline Width of dryer $(\mathrm{w})$ & $1.5 \mathrm{~m}$ & Humidity ratio before drying $\left(\mathrm{W}_{\mathrm{al}}\right)$ & $0.019 \mathrm{~kg} / \mathrm{kg}$ water \\
& & Humidity ratio after drying $\left(\mathrm{W}_{\mathrm{a} 2}\right)$ & $0.021 \mathrm{~kg} / \mathrm{kg}$ water \\
\hline
\end{tabular}


following equation:

$$
\eta_{d}=\frac{M_{r} L}{A_{c} G+P_{f}+P_{h}} \times 100 \%
$$

The exergy values are calculated from the first-law energy balance using the characteristics of the working medium. The general form of the exergy equation applicable for a steady flow system can be expressed as (Akbulut and Durmus, 2010):

For exergy inflow of drying chamber which can be written as follows:

$$
E x_{d c i}=m_{f} C\left[\left(T_{d c i^{-}} T_{a}\right)-T_{a} \ln \left(\frac{T_{d c i}}{T_{a}}\right)\right]
$$

Similarly, for exergy outflow of drying chamber following relation can be expressed as:

$$
E x_{d c o}=m_{f} C\left[\left(T_{d c o}-T_{a}\right)-T_{a} \ln \left(\frac{T_{d c o}}{T_{a}}\right)\right]
$$

The exergy efficiency can be defined as the ratio of energy use in the drying of the product to exergy of the drying air supplied to the system. The exergy efficiency can be thus written as (Akpinar, 2010; Akbulut and Durmus, 2010):

$$
\eta_{E x}=\frac{E x_{d c o}}{E x_{d c i}} \times 100
$$

\section{Overall heat loss from the collector}

It is convenient from the point of view of analysis to express the heat lost from the collector in terms of an overall loss coefficient defined by the equation (Sukhatme, 1997):

$$
\frac{q_{l}}{A_{p}}=U_{l}\left(T_{p m}-T_{a}\right)
$$

\begin{tabular}{|c|c|}
\hline Name of materials & Amount \\
\hline PVC sheet & $2058 \times 2058 \times 12 \mathrm{~mm}^{3}$ \\
\hline $\begin{array}{ll}\text { MS } & \text { Angle bar } \\
\text { Bar } & \text { Square bar }\end{array}$ & $\begin{array}{l}66,400 \times 318 \mathrm{~mm}^{2} \\
96,300 \times 8 \mathrm{~mm}^{2}\end{array}$ \\
\hline Wheel & 8 no. (101.6 mm diameter) \\
\hline Poly coated wire net & $4087 \times 4087 \mathrm{~mm}^{2}$ \\
\hline Bearing & 16 no. (10 mm dia.) \\
\hline Polythene & $2700 \times 2700 \times 1.5 \mathrm{~mm}^{3}$ \\
\hline $\begin{array}{l}\text { Nut and bolt } \\
\text { diameter) }\end{array}$ & 100 pcs (12.7 mm diameter), 20 pcs (25.4 mm \\
\hline Corrugated iron sheet & $1500 \times 2700 \times 1 \mathrm{~mm}^{3}$ \\
\hline Paint & $2 \mathrm{~L}$ black and $2 \mathrm{~L}$ yellow \\
\hline Solar panel & $609.6 \times 304.8 \times 25.4 \mathrm{~mm}^{3}(24 \mathrm{~W}$, mono-crystalline) \\
\hline Fan & 1 no. (150 mm die), $12 \mathrm{~W}$ DC \\
\hline
\end{tabular}

The heat lost from the collector is the sum of the heat lost from

Table 2. Specification of materials. the top, the bottom and the sides. Thus we can write:

$q_{l}=q_{t}+q_{b}+q_{s}$

Each of these losses is also expressed in terms of coefficients called the top loss coefficient, the bottom loss coefficient and the side loss coefficient and defined by the equations:

$q_{t, b, s}=U_{t, b, s} A_{p}\left(T_{p m}-T_{a}\right)$

\section{Top loss coefficient}

The top loss coefficient can be obtained by the following relation (Sukhatme, 1997):

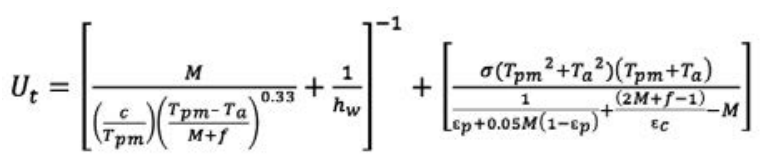

where:

$f=\left(1-0.04 h_{w}+0.005 h_{w}{ }^{2}\right)(1+0.091 M)$

$\mathrm{c}=365.9\left(1-0.00883 \beta+0.0001298 \beta^{2}\right)$

Convective heat transfer coefficient at the top cover has been generally calculated so far, from the following empirical correlation as (Sukhatme, 1997):

$h_{w}=5.7+3.8 V_{w}$

\section{The bottom heat loss coefficient}

The bottom loss coefficient $\mathrm{U}_{\mathrm{b}}$ is evaluated by considering conduction and convection losses from the absorber plate in the downward direction through the bottom of the collector. (Sukhatme, 1997):

$$
U_{b}=\frac{K_{i}}{X_{i}}
$$

\section{Side loss coefficient}

If the dimensions of the absorber plate are $\mathrm{L}_{1} \times \mathrm{L}_{2}$ and the height of the collector casing is $\mathrm{L}_{3}$, then the area across which heat flows sideways in $2\left(\mathrm{~L}_{1}+\mathrm{L}_{2}\right) \mathrm{L}_{3}$. The temperature drop across which the heat flow occurs varies from $\left(\mathrm{T}_{\mathrm{pm}}-\mathrm{T}_{\mathrm{a}}\right)$ at the absorber plate level to zero both at the top and bottom. Assuming, therefore, that the average temperature drop across the side insulation is $\left(\mathrm{T}_{\mathrm{pm}}-\mathrm{T}_{\mathrm{a}}\right) / 2$ and that the thickness of this insulation is $\delta_{\mathrm{s}}$, we have (Sukhatme, 1997):

$q_{s}=2 L_{3}\left(L_{1}+L_{2}\right) k_{i} \frac{\left(T_{p m}-T_{a}\right)}{2 \delta_{s}}$

Again, $q_{s}=U_{s} A_{p}\left(T_{p m}-T_{a}\right)$

Thus,

$$
U_{s}=\frac{\left(L_{1}+L_{2}\right) L_{3} k_{i}}{L_{1} L_{2} \delta_{s}}
$$




\section{Germination test}

The pepper was soaked in clean water for one hour. After draining water the seeds were placed on the surface of soaked blotter papers in the petri dishes. Twenty numbers of petri dish were used for seed germination test while 10 numbers for each drying system. About 100 numbers of seed were placed in each petri dish. The average room temperature and relative humidity was $20^{\circ} \mathrm{C}$ and $76 \%$ respectively. The germination was counted up to 6 days. (Sultana, 2001).

\section{Colour test}

The colour of dried red peppers was quantified by using a Minolta (CR-400) Chromameter (Osaka, Japan). L*, a* and $b^{*}$ values were measured to describe three dimensional colour space and interpreted as follows: $\mathrm{L}^{*}$ is the brightness/lightness or whiteness ranging from no reflection for black $(\mathrm{L}=0)$ to perfect diffuse reflection for white $(\mathrm{L}=100)$. The value $\mathrm{a}^{*}$ is the redness ranging from negative values for green to positive values for red. The value $b^{*}$ is the yellowness ranging from negative values for blue and positive values for yellow. The data were presented as means of nine independent measurements for each treatment (Hossain and Bala, 2006).

\section{Results and discussion}

The cabinet type solar dryer was designed and fabricated to dry red pepper over a collector and dryer area of $4.00 \mathrm{~m}^{2}$ and $7.5 \mathrm{~m}^{2}$

A

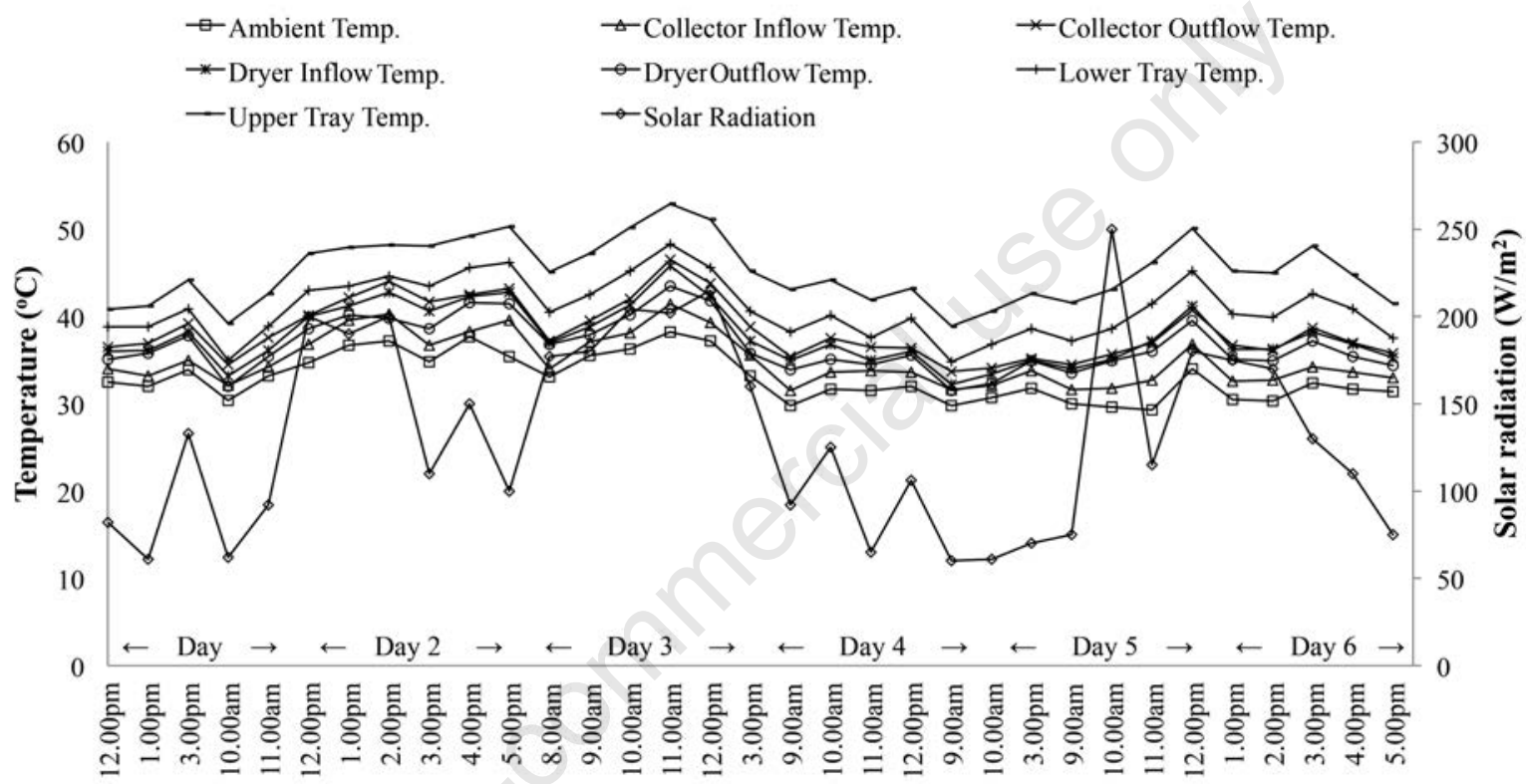

B $\rightarrow$ Ambient Relative Humadity $\quad \rightarrow$ Exhaust Relative Humidity $\rightarrow$ Solar Radiation

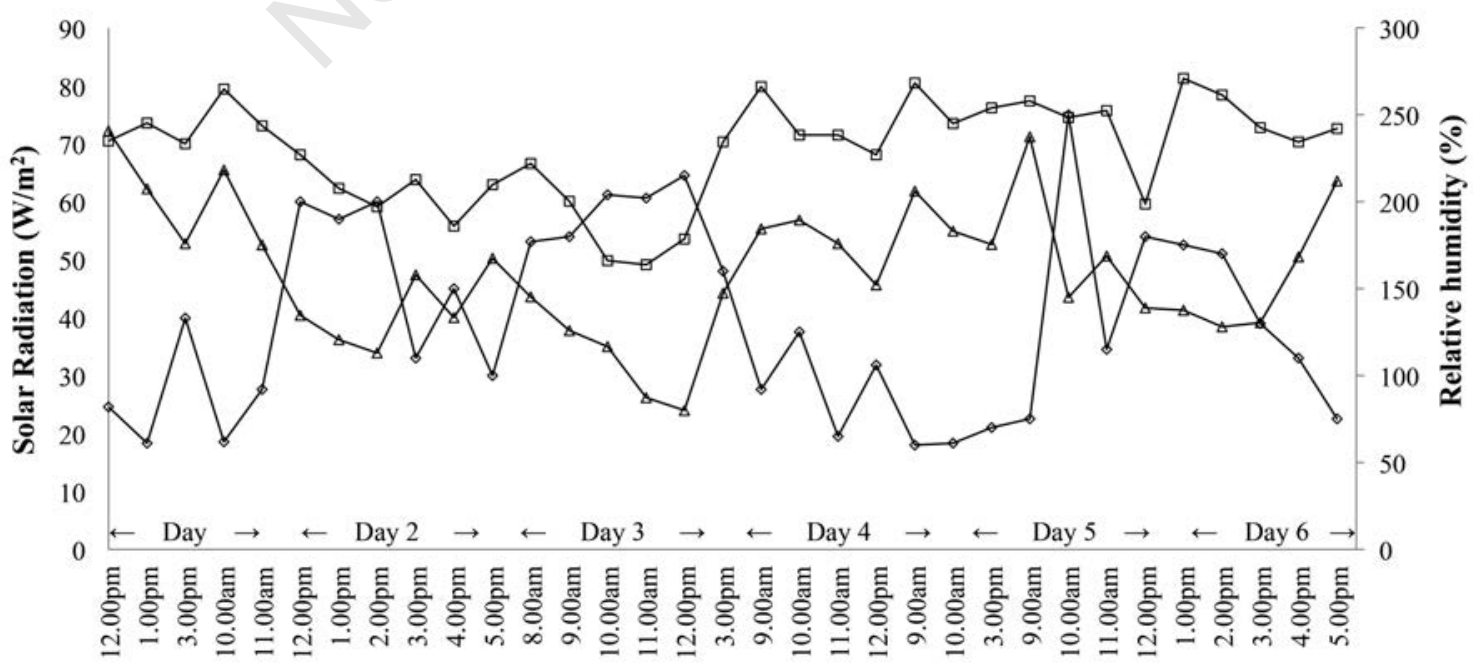

Figure 2. A) Temperature variation on different solar radiation; B) relative humidity variation on different solar radiation. 
respectively. The prototype of the cabinet type solar dryer was fabricated in the workshop of Spices Research Centre, Bogra, Bangladesh. The dryer was fabricated by angle bar, square bar, PVC sheet, polythene sheet, wheel, nut and bolt, poly coated wire net, corrugated iron sheet, paint, solar panel and exhaust fan. Hossain and Bala (2006) designed, fabricated and installed a Hohenheim type solar tunnel dryer in Bangladesh Agricultural University, Mymensingh where the area of the dryer unit was same as that of the collector. In case of our cabinet dryer, two trays, namely upper and lower are placed in column and reduce the area significantly, which is not possible in case of tunnel dryer.

The upper tray and lower tray pepper drying needed 36 and 41 $\mathrm{h}$ to reduce moisture from $73 \%$ (wet basis) to $10 \%$ (wet basis) respectively and found $9 \mathrm{~kg}$ dried pepper from $30 \mathrm{~kg}$ fresh red ripe pepper. In contrast, open sun drying took $85 \mathrm{~h}$ reducing moisture from $73 \%$ (wet basis) to $11 \%$ (wet basis) and produced $2.43 \mathrm{~kg}$ dried pepper from $8 \mathrm{~kg}$ red ripe pepper. The drying character demonstrates that cabinet solar drying is quicker than that of conventional sun drying method. The average ambient temperature, upper tray temperature, lower tray temperature, ambient relative humidity, exhaust relative humidity and solar radiation during experiment was $33^{\circ} \mathrm{C}, 45^{\circ} \mathrm{C}, 41^{\circ} \mathrm{C}, 69 \%, 48 \%$ and $133 \mathrm{~W} / \mathrm{m}^{2}$ respectively shown in Figure 2A and B. Fudholi et al. (2013) studied performance of solar drying system for red pepper. Red chili was dried to final moisture content of $10 \%$ w.b from $80 \%$ w.b in 33 $\mathrm{h}$ using this system. In his study the average solar radiation was $420 \mathrm{~W} / \mathrm{m}^{2}$ while in our study the average solar radiation was 133 $\mathrm{W} / \mathrm{m}^{2}$. This represent that even though the sun intensity is low, our designed solar dryer is capable in reducing moisture with no significant time differences.

The average upper tray temperature $\left(45^{\circ} \mathrm{C}\right)$ and drying rate $(1.26 \mathrm{~kg} / \mathrm{h})$ was higher than that of average lower tray temperature $\left(41^{\circ} \mathrm{C}\right)$ and drying rate $(1.13 \mathrm{~kg} / \mathrm{h})$. In contrast, open sun drying represented poor drying rate $(0.65 \mathrm{~kg} / \mathrm{h})$. The average mass flow rate in the dryer was $0.07 \mathrm{~kg} / \mathrm{s}$ over the vent area, average air speed and air density of $0.04 \mathrm{~m}^{2}, 2.18 \mathrm{~m} / \mathrm{s}$ and $1.13 \mathrm{~kg} / \mathrm{m}^{3}$ respectively. The drying characteristics curve for upper tray, lower tray and open sun pepper is shown as in Figure 3.
The average global radiation was measured as about $133 \mathrm{~W} / \mathrm{m}^{2}$ ranged from $60 \mathrm{~W} / \mathrm{m}^{2}$ to $250 \mathrm{~W} / \mathrm{m}^{2}$. Similarly, the flux incidence on collector was calculated as about $128 \mathrm{~W} / \mathrm{m}^{2}$ ranged from 58 $\mathrm{W} / \mathrm{m}^{2}$ to $241 \mathrm{~W} / \mathrm{m}^{2}$. Moreover, the flux absorbed on the collector was calculated as about $103 \mathrm{~W} / \mathrm{m}^{2}$ ranged from $58 \mathrm{~W} / \mathrm{m}^{2}$ to 193 $\mathrm{W} / \mathrm{m}^{2}$. The declination angle was achieved $11.23^{\circ}$ for experiment period of $20^{\text {th }}$ April while the hour angle was considered for 09:30 a.m., about $37.5^{\circ}$. To calculate clearness index the value a,b was assumed about 0.28 and 0.42 , considering location of Calcutta, India as there is no available data for Bogra, Bangladesh and both the city are adjacent to each other and weather condition is almost same. The refractive angle was calculated over a refractive index of 1.53. The extinction coefficient and emissivity was considered $20 \mathrm{~m}^{-1}$ and 0.95 respectively (Sukhatme, 1997). The relationship among global radiation, flux incidence and flux absorbed on the collector is shown in the Figure 4.

The average collector efficiency was approximately $48 \%$, which was maximum $(73 \%)$ on $3^{\text {rd }}$ day of drying, at 11:00 a.m., over a solar radiation of $202 \mathrm{~W} / \mathrm{m}^{2}$, at a mass flow rate of $0.11 \mathrm{~kg} / \mathrm{s}$. However, minimum $(20 \%)$ was obtained on $5^{\text {th }}$ day of drying, at 03.00 p.m., over a solar radiation of $70 \mathrm{~W} / \mathrm{m}^{2}$, at a mass flow rate of $0.04 \mathrm{~kg} / \mathrm{s}$. However, it is noticeable that, collector efficiency increased with the increase of solar radiation and vice versa shown in Figure 5.

System drying efficiency was obtained, $34 \%$, to reduce $22 \mathrm{~kg}$ water from $30 \mathrm{~kg}$ pepper, over a latent heat $\mathrm{L}=2400 \mathrm{~kJ} / \mathrm{kg}(666.06$ $\mathrm{W} \mathrm{h} / \mathrm{kg})$, average drying time $(38.5 \mathrm{~h})$, average solar radiation, $\mathrm{I}_{\mathrm{g}}=133 \mathrm{~W} / \mathrm{m}^{2}$, over a fan power of $43.2 \mathrm{kWh}$. Fuller et al. (2005) studied on feasibility study on solar dryer for pepper and found average collector and system drying efficiency of $30 \%$ and $14.5 \%$ respectively.

Lingayat et al. (2017) designed a solar collector area of $2 \mathrm{~m}^{2}$ for drying banana. The size of the drying cabinet is $1 \times 0.4 \times 1 \mathrm{~m}$ (width, depth, and height). The moisture content of banana was reduced from initial value of $356 \%(\mathrm{db})$ to final moisture content of $16 \%$, $19 \%, 21 \%, 31 \%$, and $42 \%(\mathrm{db})$ for Tray 1 , Tray 2 , Tray 3 , Tray 4 , and open sun drying respectively. The average thermal efficiency of the collector was found to be $32 \%$ and that of drying chamber was $22 \%$.

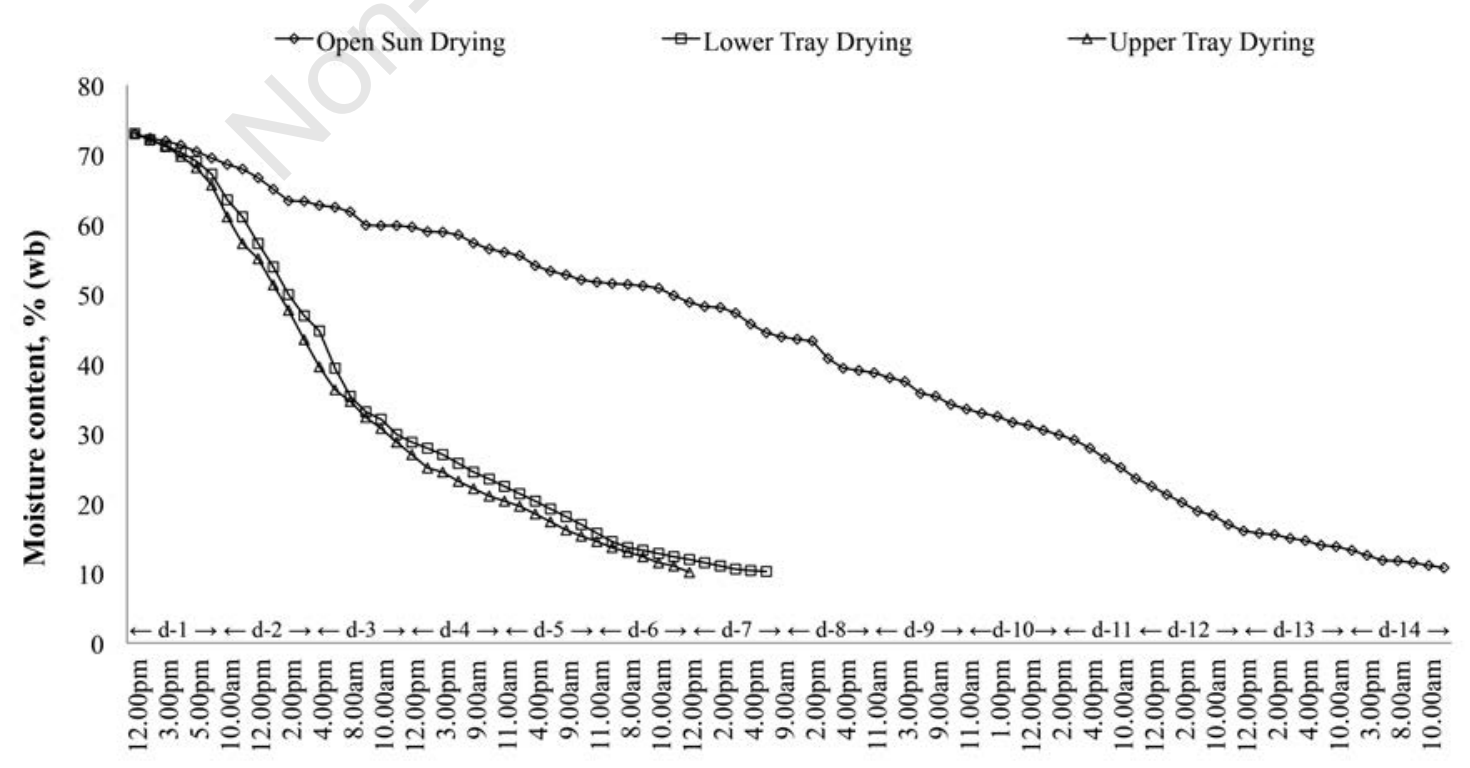

Figure 3. Drying curve of pepper. 
The average exergy inflow was $27 \mathrm{~W}$, where the maximum (77 $\mathrm{W})$ was in $3^{\text {rd }}$ day of drying, at 11:00 a.m. over a solar radiation of $202 \mathrm{~W} / \mathrm{m}^{2}$, while the lowest $(3 \mathrm{~W})$ was on $5^{\text {th }}$ day, at 09:00 a.m. over a solar radiation of $60 \mathrm{~W} / \mathrm{m}^{2}$. Similarly, average exergy outflow is $17 \mathrm{~W}$, where the maximum and minimum was $59 \mathrm{~W}$ and 2 $\mathrm{W}$ at $6^{\text {th }}$ day of drying, at 10:00 a.m., for $250 \mathrm{~W} / \mathrm{m}^{2}$ and at $5^{\text {th }}$ day of drying, at 10:00 a.m., for $61 \mathrm{~W} / \mathrm{m}^{2}$ respectively. However, average exergy efficiency was obtained $63 \%$, whereas maximum and minimum was $93 \%, 6^{\text {th }}$ day, at $10: 00$ a.m., for $250 \mathrm{~W} / \mathrm{m}^{2}$ and $23 \%$, at $2^{\text {nd }}$ day, 10:00 a.m., for $200 \mathrm{~W} / \mathrm{m}^{2}$ respectively. Our designed dryer demonstrated better exergy efficiency in comparison to the study conducted by Fudholi et al. (2014) who obtained values for drying red pepper varied between $43 \%$ and $97 \%$ with an average of $57 \%$. Exergy inflow, outflow, and loss follow similar patterns as similarly reported by Chowdhury et al. (2011) and Akpinar (2010) shown in Figure 6. Rabha et al. (2017) developed a forced convection solar tunnel dryer integrated with a shell and tube based latent heat storage module was designed and fabricated. Ghost pepper pepper and sliced ginger were successfully dried in the dryer in 42 $\mathrm{h}$ and $33 \mathrm{~h}$ in the drying air temperature range of $42-61^{\circ} \mathrm{C}$ and $37-$ $57^{\circ} \mathrm{C}$, respectively. Energy and exergy analyses of the drying processes of the two products were performed. The results showed

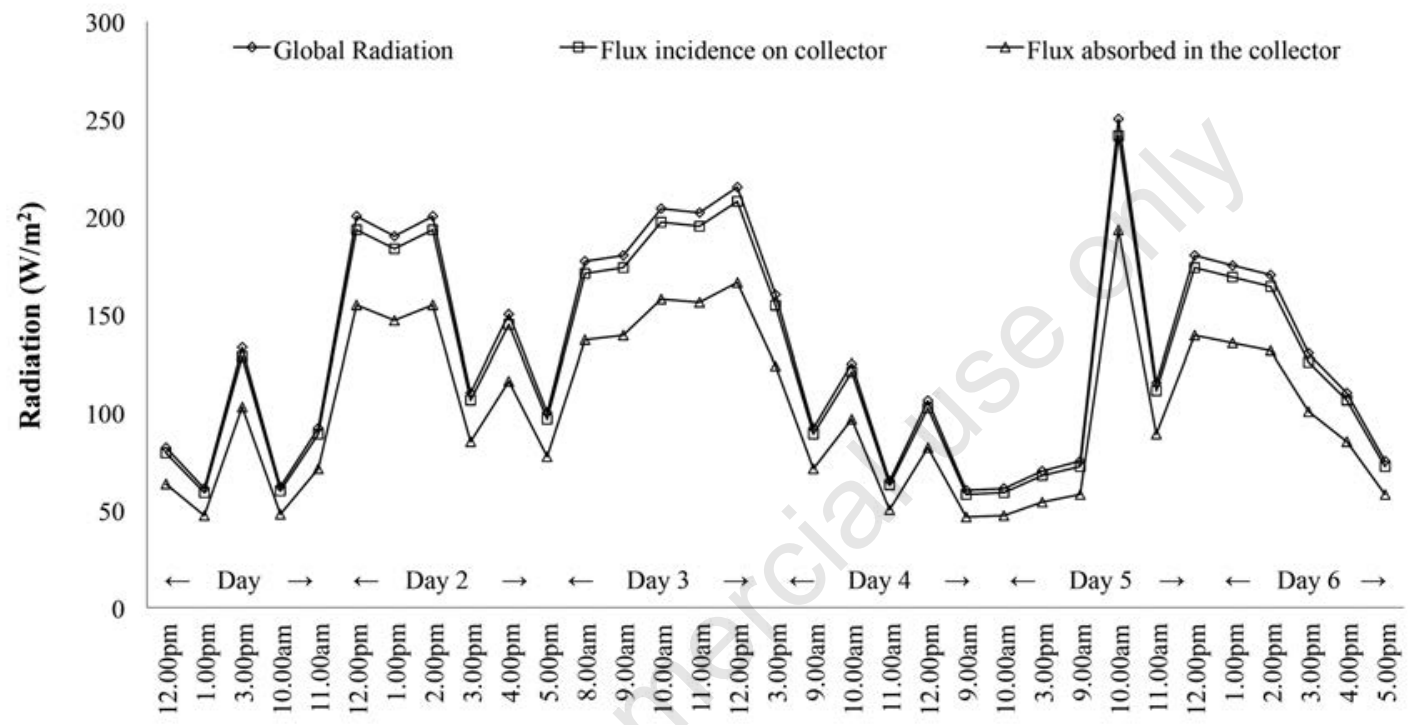

Figure 4. Flux characteristics on different period of drying time.

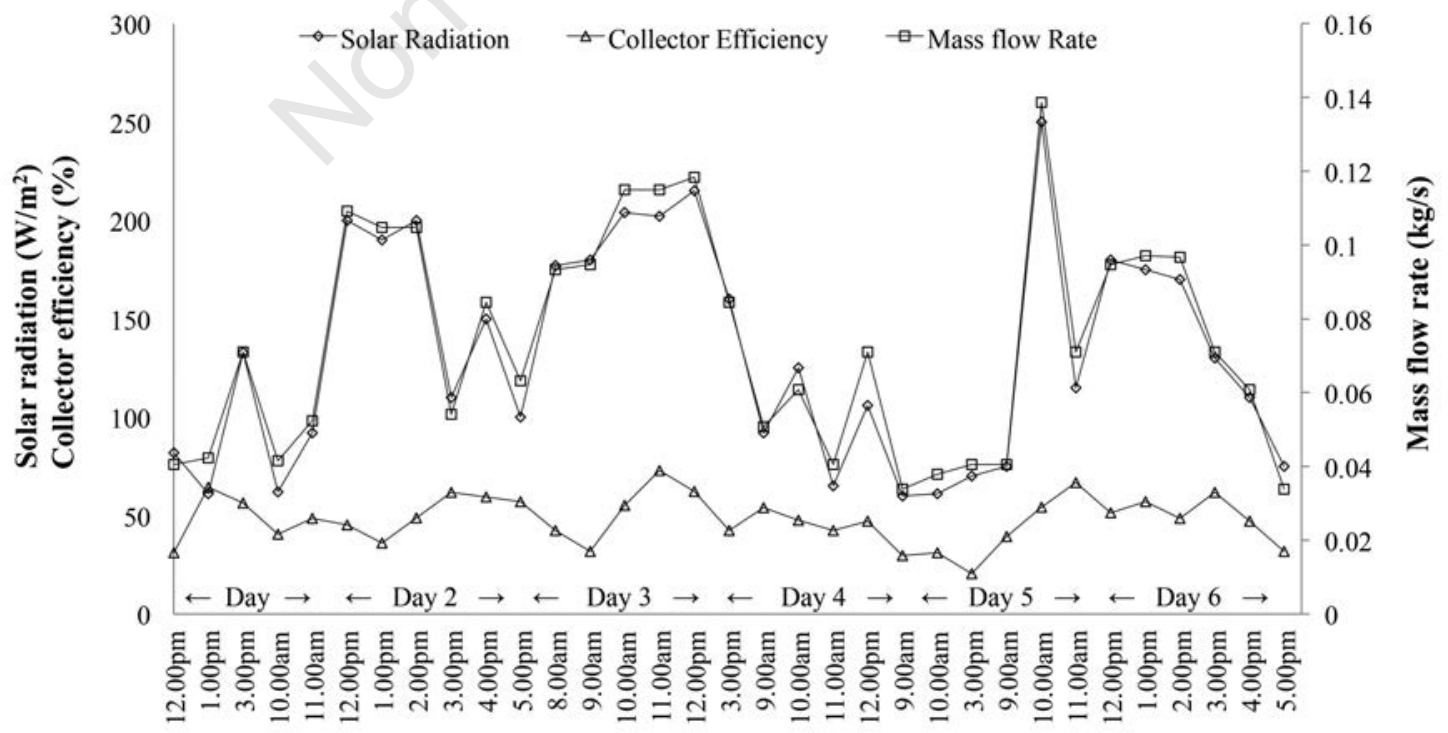

Figure 5. Variation of collector efficiency. 
that the thermal efficiencies of the first and the second solar air heaters varied between $22 \%$ and $40 \%$ and $10 \%$ and $20 \%$, respectively. The average overall thermal efficiency of the air heaters array varied between $23 \%$ and $23 \%$. When the ghost pepper was dried, the exergy efficiency of the drying chamber was in the range of $21 \%-98 \%$ with an average of $63 \%$, and it was $4 \%-96 \%$ with an average of $47 \%$, while the ginger was dried. The exegetic efficiency increased with advancing in drying time, and high exergetic efficiency was recorded in the last few hours of the drying operation of the consecutive drying days.

The average rate of top collector loss was $37 \mathrm{~W} / \mathrm{m}^{2}$, ranged from $13 \mathrm{~W} / \mathrm{m}^{2}$ to $62 \mathrm{~W} / \mathrm{m}^{2}$. Similarly, the average rate of bottom and side energy loss was $20 \mathrm{~W} / \mathrm{m}^{2}$ and $3 \mathrm{~W} / \mathrm{m}^{2}$ ranged from 9 $\mathrm{W} / \mathrm{m}^{2}$ to $30 \mathrm{~W} / \mathrm{m}^{2}$ and $2 \mathrm{~W} / \mathrm{m}^{2}$ to $5 \mathrm{~W} / \mathrm{m}^{2}$ respectively. To calculate top loss coefficient, the convective heat transfer coefficient was calculated over different air speed for collector tilt of $23.5^{\circ}$ and assuming one number of plastic cover. In this case, collector $\left(\varepsilon_{\mathrm{c}}\right)$ and absorber $\left(\varepsilon_{\mathrm{p}}\right)$ emissivity was considered 0.88 and 0.95 (Sukhatme, 1997). Similarly, in calculating bottom loss, the thermal conductivity of PVC sheet is $0.12 \mathrm{~W} / \mathrm{m}-\mathrm{K}$ (Anonymous, 2016b) over a thickness of $0.04 \mathrm{~m}$. Likewise, the side loss coefficient was calculated for a given length, width and depth of the col-

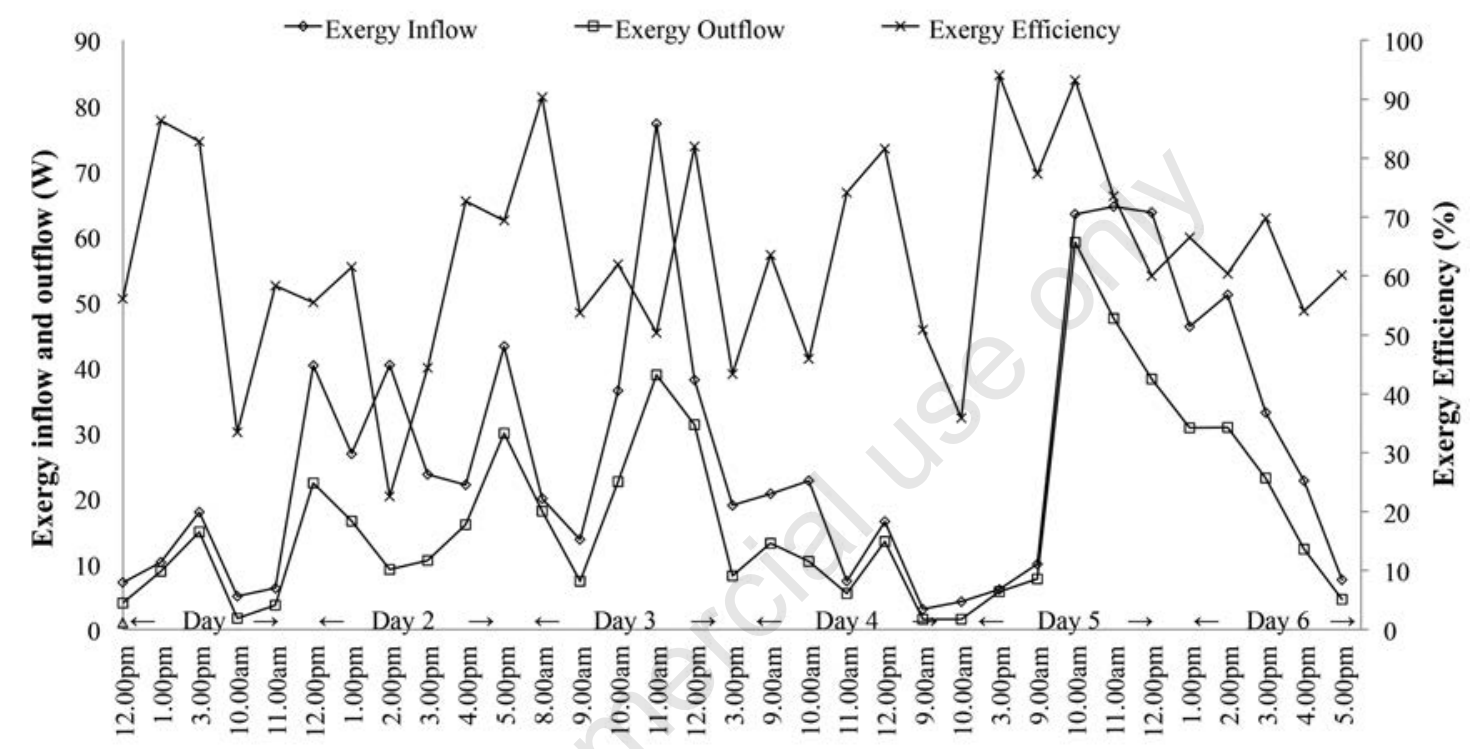

Figure 6. Exergy at different period of drying time.

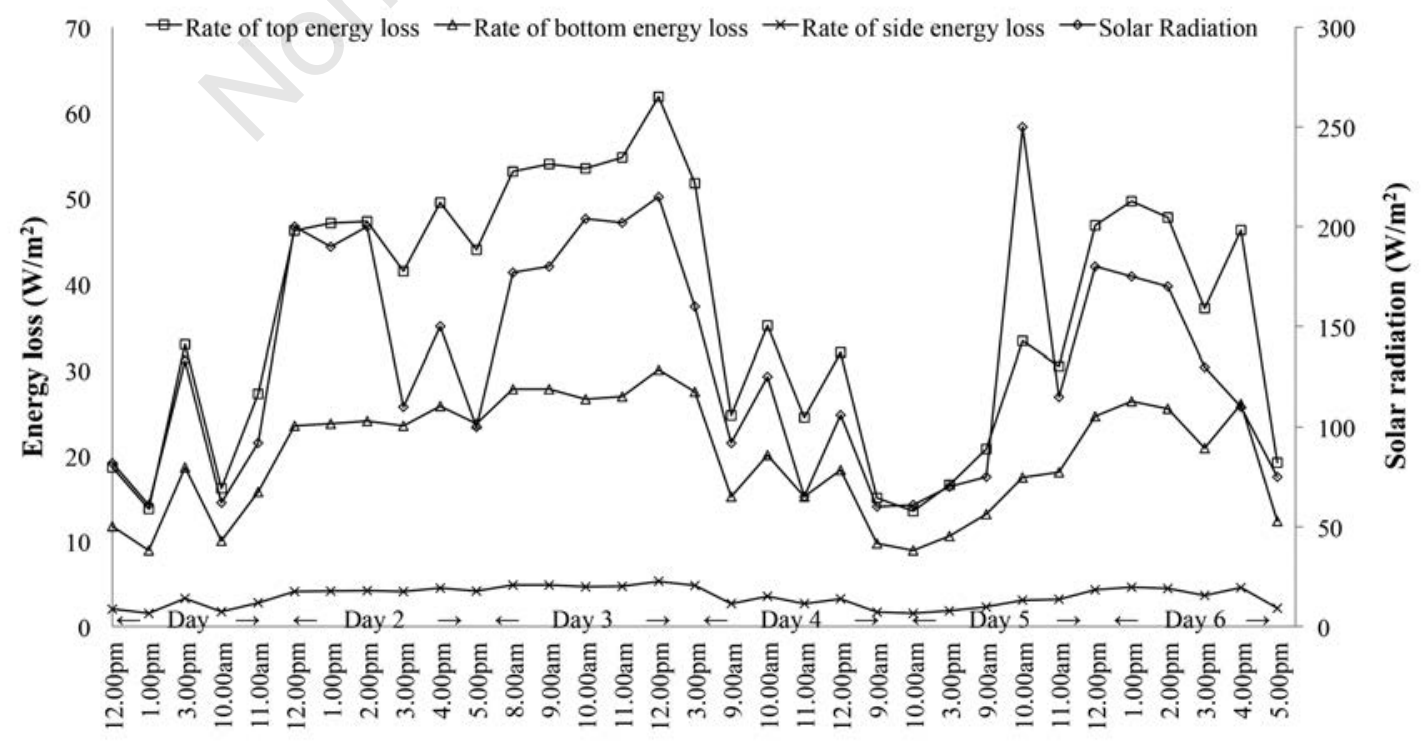

Figure 7. Energy loss through collector at different solar radiation. 
lector. The energy loss phenomenon is shown in the following Figure 7. The upper tray, lower tray and open sun drying pepper seed germination were $76 \%, 81 \%$ and $85 \%$ respectively. However, the seed germination between dryer and open sun drying shows no significant statistical difference $(\mathrm{P} \geq 0.01)$. Krishnamurthy (1995) observed that higher seed quality in sun drying among traditional methods (sun and shade), whereas, in mechanical drying at different air temperatures, seeds dried under $40^{\circ} \mathrm{C}$ temperature showed higher germination. As the temperature in the dryer was higher about $45^{\circ} \mathrm{C}$ and $41^{\circ} \mathrm{C}$ for upper and lower tray respectively, which is believed to be responsible for diminishing seed germination in case of cabinat drying compared to open sun drying. Christinal and Tholkkappian (2012) also mentioned that pepper dried by sun and mechanical dryer at $37^{\circ} \mathrm{C}$ gave higher germination.

The average values of three chromatic scales $\left(L^{*}, a^{*}, b^{*}\right)$ measured on lower tray pepper were $L^{*}=42.28, a^{*}=27.1$ and $b^{*}=54.69$, upper tray pepper were $\mathrm{L}^{*}=43.6, \mathrm{a}^{*}=24.7$ and $\mathrm{b}^{*}=56.6$ and open sun pepper were $L^{*}=49.5, a^{*}=21.1$ and $b^{*}=62.5$, The redness $\left(a^{*}\right)$ value of lower tray pepper was higher than that of the upper tray and open sun pepper powder, while the darkness ( $\left.\mathrm{L}^{*}\right)$ and yellowness $\left(b^{*}\right)$ was higher in case of open sun and upper tray pepper power which means direct exposure of sunlight diminishes the quality of colour. The redness value of solar drying was significantly $(\mathrm{P} \leq 0.01)$ higher than that of open sun drying. Similar result was also found by Hossain (2006) that colour values obtained from conventional sun dried green pepper was significantly lower than those obtained from solar tunnel and improved sun dried green pepper.

\section{Conclusions}

A cabinet type solar dryer was designed and fabricated by angle bar, square bar, PVC sheet, polythene sheet, wheel, nut and bolt, poly coated wire net, corrugated iron sheet, paint, solar panel and exhaust fan over a collector and dryer area of $4.00 \mathrm{~m}^{2}$ and 7.5 $\mathrm{m}^{2}$ respectively in Spices Research Centre, Shibganj, Bogra, Bangladesh.

To dry pepper the upper tray and lower tray needed 36 and 41 $\mathrm{h}$ to reduce moisture from $73 \%$ (wet basis) to $10 \%$ (wet basis) respectively and found $9 \mathrm{~kg}$ dried pepper from $30 \mathrm{~kg}$ fresh red ripe pepper. In contrast, open sun drying took $85 \mathrm{~h}$ reducing moisture from $73 \%$ (wet basis) to $11 \%$ (wet basis) and produced $2.43 \mathrm{~kg}$ dried pepper from $8 \mathrm{~kg}$ red ripe pepper.

The average ambient temperature, upper tray temperature, lower tray temperature, ambient relative humidity and exhaust relative humidity during experiment was $33^{\circ} \mathrm{C}, 45^{\circ} \mathrm{C}, 41^{\circ} \mathrm{C}, 69 \%$ and $48 \%$ respectively.

The average mass flow rate in the dryer was $0.07 \mathrm{~kg} / \mathrm{s}$ over the vent area, average air speed and air density of $0.04 \mathrm{~m}^{2}, 2.18 \mathrm{~m} / \mathrm{s}$ and $1.127 \mathrm{~kg} / \mathrm{m}^{3}$ respectively.

The average global radiation was measured as about $133 \mathrm{~W} / \mathrm{m}^{2}$ ranged from $60 \mathrm{~W} / \mathrm{m}^{2}$ to $250 \mathrm{~W} / \mathrm{m}^{2}$. Similarly, the flux incidence on collector was calculated as about $128 \mathrm{~W} / \mathrm{m}^{2}$ ranged from 58 $\mathrm{W} / \mathrm{m}^{2}$ to $241 \mathrm{~W} / \mathrm{m}^{2}$. Moreover, the flux absorbed on the collector was calculated as about $103 \mathrm{~W} / \mathrm{m}^{2}$ ranged from $58 \mathrm{~W} / \mathrm{m}^{2}$ to 193 $\mathrm{W} / \mathrm{m}^{2}$.

The average collector efficiency was approximately $48 \%$, ranged from $20 \%-73 \%$. It is noticeable that, collector efficiency increases with the increase of solar radiation and vice versa. System drying efficiency was obtained, $34 \%$.

The average exergy inflow was $27 \mathrm{~W}$, where the maximum ranged from $3 \mathrm{~W}$ to $77 \mathrm{~W}$ Similarly, average exergy outflow is 17 $\mathrm{W}$, ranged from $2 \mathrm{~W}$ to $59 \mathrm{~W}$. Average exergy efficiency was obtained $63 \%$, ranged from $23 \%$ to $93 \%$.

The average rate of top collector loss was $37 \mathrm{~W} / \mathrm{m}^{2}$, ranged from $13 \mathrm{~W} / \mathrm{m}^{2}$ to $62 \mathrm{~W} / \mathrm{m}^{2}$. Similarly, the average rate of bottom and side energy loss was $20 \mathrm{~W} / \mathrm{m}^{2}$ and $3 \mathrm{~W} / \mathrm{m}^{2}$ ranged from 9 $\mathrm{W} / \mathrm{m}^{2}$ to $30 \mathrm{~W} / \mathrm{m}^{2}$ and $2 \mathrm{~W} / \mathrm{m}^{2}$ to $5 \mathrm{~W} / \mathrm{m}^{2}$ respectively.

The upper tray, lower tray and open sun drying pepper seed germination were $76 \%, 81 \%$ and $85 \%$ respectively. The seed germination between dryer and open sun drying shows no significant statistical difference $(\mathrm{P} \geq 0.01)$.

The redness value of lower tray pepper $\left(a^{*}=27.1\right)$ was higher followed by upper tray $\left(a^{*}=24.7\right)$ and open sun pepper powder $\left(a^{*}=21.1\right)$. The darkness $\left(L^{*}\right)$ and yellowness $\left(b^{*}\right)$ was higher in case of open sun were $\left(L^{*}=49.5\right.$ and $\left.b^{*}=62.5\right)$ followed by upper tray pepper power $\left(\mathrm{L}^{*}=43.6\right.$, and $\left.b^{*}=56.6\right)$ and lower tray pepper $\left(\mathrm{L}^{*}=42.28, \mathrm{a}^{*}=27.1\right.$ and $\left.\mathrm{b}^{*}=54.69\right)$ which means direct exposure of sunlight diminishes the quality of colour. The redness value of fabricated solar drying was significantly $(\mathrm{P} \leq 0.01)$ higher than that of open sun drying.

\section{Nomenclature}

a,b Constants obtained by fitting data

$\mathrm{A}_{\mathrm{c}} \quad$ Collector area $\left(\mathrm{m}^{2}\right)$

$A_{d} \quad$ Drying area $\left(\mathrm{m}^{2}\right)$

$\mathrm{A}_{\mathrm{p}} \quad$ Area of absorber $\left(\mathrm{m}^{2}\right)$

$A_{t} \quad$ Area of each tray $\left(\mathrm{m}^{2}\right)$

C Specific heat of air $(\mathrm{kJ} / \mathrm{kg}-\mathrm{K})$

$\mathrm{D}_{0} \quad$ Outlet diameter $(\mathrm{cm})$

$\mathrm{D}_{\mathrm{r}} \quad$ Drying rate $(\mathrm{kg} / \mathrm{h})$

E Energy $(\mathrm{kJ})$

Exdci Exergy in dryer chamber inflow (W)

Exdco Exergy in dryer chamber outflow (W)

Ex loss $\quad$ Exergy loss (W)

$\mathrm{h}_{\mathrm{w}}$

$\mathrm{I}_{\mathrm{d}}$

Wind heat transfer coefficient $\left(\mathrm{W} / \mathrm{m}^{2}{ }^{\circ} \mathrm{C}\right)$

Diffuse radiation $\left(\mathrm{W} / \mathrm{m}^{2}\right)$

Beam radiation $\left(\mathrm{W} / \mathrm{m}^{2}\right)$

Global radiation $\left(\mathrm{W} / \mathrm{m}^{2}\right)$

Flux on tilted surface $\left(\mathrm{W} / \mathrm{m}^{2}\right)$

Extinction coefficient

Thermal conductivity $(\mathrm{W} / \mathrm{m}-\mathrm{K})$

clearness index

Latent heat $(\mathrm{kJ} / \mathrm{kg})$

Length of collector (m)

Length of tray $(\mathrm{m})$

Number of glass cover

Moisture to be removed $(\mathrm{kg})$

Initial moisture content $(\%)$

Final moisture content $(\%)$

Mass flow rate $(\mathrm{kg} / \mathrm{s})$

Number of tray

Day of the year

Outlet area $\left(\mathrm{m}^{2}\right)$

Fan power (W)

Heater power (W)

Useful heat gain (W)

Rate of heat loss from bottom (W)

Rate of heat loss (W)

Temperature in dryer chamber inflow $\left({ }^{\circ} \mathrm{C}\right)$

Rate of heat loss from top (W)

Reflective index

Tilt factor for beam radiation

Tilt factor for diffuse radiation

Tilt factor for reflected radiation

Heat absorbs in collector $\left(\mathrm{W} / \mathrm{m}^{2}\right)$

Monthly average sunshine hour per day (h)

Maximum possible day length per day (h)

Spreading density $\left(\mathrm{kg} / \mathrm{m}^{2}\right)$

Solar insolation (kJh/day)

Drying time (h) 


\begin{tabular}{|c|c|}
\hline $\mathrm{T}_{\mathrm{a}}$ & Ambient temperature $\left({ }^{\circ} \mathrm{C}\right)$ \\
\hline $\mathrm{T}_{\mathrm{d}}$ & Dryer temperature $\left({ }^{\circ} \mathrm{C}\right)$ \\
\hline $\mathrm{T}_{\mathrm{dco}}$ & Temperature in dryer chamber outflow $\left({ }^{\circ} \mathrm{C}\right)$ \\
\hline $\mathrm{T}_{\mathrm{i}}$ & Collector inflow temperature $\left({ }^{\circ} \mathrm{C}\right)$ \\
\hline $\mathrm{T}_{\mathrm{o}}$ & Collector outflow temperature $\left({ }^{\circ} \mathrm{C}\right)$ \\
\hline $\mathrm{T}_{\mathrm{pm}}$ & Mean absorber surface temperature $\left({ }^{\circ} \mathrm{C}\right)$ \\
\hline $\mathrm{U}_{\mathrm{b}}$ & Bottom loss coefficient (W/m²-K) \\
\hline $\mathrm{U}_{1}$ & Overall loss coefficient $\left(\mathrm{W} / \mathrm{m}^{2}-\mathrm{K}\right)$ \\
\hline $\mathrm{U}_{\mathrm{s}}$ & Side loss coefficient $\left(\mathrm{W} / \mathrm{m}^{2}-\mathrm{K}\right)$ \\
\hline $\mathrm{U}_{\mathrm{t}}$ & Top loss coefficient $\left(\mathrm{W} / \mathrm{m}^{2}-\mathrm{K}\right)$ \\
\hline $\mathrm{w}$ & Width of dryer $(\mathrm{m})$ \\
\hline W & Amount of water removed $(\mathrm{kg})$ \\
\hline $\mathrm{W}_{\mathrm{p}}$ & Sample weight (kg) \\
\hline $\mathrm{V}_{\mathrm{a}}$ & Volumetric airflow rate $\left(\mathrm{m}^{3} / \mathrm{s}\right)$ \\
\hline $\mathrm{V}_{\mathrm{w}}$ & Wind speed (m/s) \\
\hline $\mathrm{W}_{\mathrm{a} 1}$ & Humidity ratio before drying, $\mathrm{kg} / \mathrm{kg}$ water \\
\hline $\mathrm{W}_{\mathrm{a} 2}$ & Humidity ratio after drying, $\mathrm{kg} / \mathrm{kg}$ water \\
\hline $\mathrm{W}_{\mathrm{t}}$ & Width of each tray (m) \\
\hline $\mathrm{X}_{\mathrm{i}}$ & Thickness of the insulation (m) \\
\hline$\theta$ & Angle of incidence $\left(^{\circ}\right)$ \\
\hline$\theta_{1}$ & Angle of incidence on collector $\left(^{\circ}\right)$ \\
\hline$\theta_{2}$ & Angle of refraction on collector $\left(^{\circ}\right)$ \\
\hline$\theta_{\mathrm{Z}}$ & Zenith angle $\left(^{\circ}\right)$ \\
\hline$\Phi$ & latitude $\left(^{\circ}\right)$ \\
\hline$\delta$ & Declination $\left(^{\circ}\right)$ \\
\hline$\alpha$ & Absorptivity \\
\hline$\tau$ & Transmissivity \\
\hline$(\tau \alpha)_{b}$ & Absorptivity-transmissivity for beam radiation \\
\hline$(\tau \alpha)_{\mathrm{d}}$ & Absorptivity-transmissivity for diffuse radiation \\
\hline$\omega$ & Hour angle $\left(^{\circ}\right)$ \\
\hline$\beta$ & Slope $\left(^{\circ}\right)$ \\
\hline$\rho$ & Density $\left(\mathrm{kg} / \mathrm{m}^{3}\right)$ \\
\hline$\rho_{\mathrm{a}}$ & Density of air $\left(\mathrm{kg} / \mathrm{m}^{3}\right)$ \\
\hline $\mathrm{q}_{\mathrm{s}}$ & Rate of heat loss from side (W) \\
\hline$\rho_{\mathrm{I}}, \rho_{\mathrm{I}}$ & Reflectivity \\
\hline$\eta$ & Efficiency $(\%)$ \\
\hline$\eta_{\mathrm{c}}$ & Collector efficiency $(\%)$ \\
\hline$\eta_{\mathrm{d}}$ & Dryer efficiency $(\%)$ \\
\hline$\eta$ Ex & Exergy efficiency $(\%)$ \\
\hline$\varepsilon \mathrm{P}$ & Emissivity of absorber \\
\hline$\varepsilon_{\mathrm{c}}$ & Emissivity of cover \\
\hline$\delta_{c}$ & Thickness of bottom insulation (m) \\
\hline$\delta_{\mathrm{s}}$ & Thickness of side insulation (m) \\
\hline
\end{tabular}

\section{References}

Akbulut A., Durmus A. 2010. Energy and exergy analyses of thin layer drying of mulberry in a forced solar dryer. Energy 35:1754-63.

Akpinar E.K. 2010. Drying of mint leaves in solar dryer and under open sun: modelling. performance analyses. Energy Conversion Manage. 51:2407-18.

Anonymous. 2016a. Project S1 Solid Modelling with SolidWorks. Available from: http://booksite.elsevier.com/9780123985132

Anonymous. 2016b. Thermal Properties of Plastic Materials. Available from: www.professionalplastics.com

Azaizia Z., Sami K., Aymen E., Ilhem H., Amen A.G. 2017. Investigation of a new solar greenhouse drying system for peppers. Int. J. Hydr. Energy. 42:8818-26.

Bala B.K. 1998. Solar drying systems. Agrotech Publishing
Academy, Udaipur, India.

Chowdhury M.M.I., Bala B.K., Haque M.A. 2011. Energy and exergy analysis of the solar drying of jackfruit leather. Biosyst. Engine. 110:222-9.

Christinal V., Tholkkappian P. 2012. Seed quality in chilli influenced by the different types of drying methods. Int. J. Recent Sci. Res. 3:766-70.

Fudholi A., Othman M.Y., Ruslan M.H., Sopian K. 2013. Drying of Malaysian Capsicum annuum L. (red chili) dried by open and solar drying. Int. J. Photoenerg. 1-9.

Fudholi A., Sopian K., Yazdi M.H., Ruslan M.H., Gabbasa M., Kazem H.A. 2014. Performance analysis of solar drying system for red chili. Solar Energy 99:47-54.

Fuller R.J., Lhendup T., Aye L. 2005. Technical and financial evaluation of a solar dryer in Bhutan. ANZSES Conference, Dunedin.

Hossain M.A. 2003. Forced convection solar drying of chilli. Ph.D. thesis. Bangladesh Agricultural University, Mymensingh, Bangladesh.

Hossain M.A., Bala B.K. 2006. Drying of hot chilli using solar tunnel dryer. Solar Energ. 81:85-92.

Hossain M.A. 2011. Upscalling and adoption of hybrid dryer for quality grain seed production. Project completion report. Bangladesh Agricultural Research Institute (BARI), Gazipur, Bangladesh.

Joshua F. 2008. Design, construction and testing of simple solar maize dryer. Leonardo Electr. J. Pract. Technol. 13:122-30.

Krishnamurthy V. 1995. Effect of harvesting stages, drying, seed extraction and size grading on seed yield and quality in pepper (Capsicum annuum L.). M.Sc. (Agri.) Thesis. University of Agricultural Sciences, Bangalore, India.

Lingayat A., Chandramohan V.P., Raju, V.R.K. 2017. Design, development and performance of indirect type solar dryer for banana drying, International Conference on Recent Advancement in Air Conditioning and Refrigeration (RAAR). 10-12 November 2016. Energy Procedia. 10:409-16.

Mohanraj M., Chandrasekar P. 2009. Performance of a forced convective solar dryer integrated with gravel as heat storage material for pepper drying. J. Engine. Sci. Technol. 4:305-14.

Muhlbauer W., Esper A., Muller J. 1993. Solar energy in agriculture. ISES Solar World Congress, August 23-27, Budapest, Hungary.

Pangavhane D.R., Sawhney R.L, Sarsavadia P.N. 2002. Design, development and performance testing of a new natural convection solar dryer. Energy. 27:579-90.

Rabha D.K., Muthukumar P., Somayaji C. 2017. Energy and exergy analyses of the solar drying processes of ghost pepper and ginger. Renew. Energy. 105:764-73.

Shakir U.H.K., Towfiq U.R., Shahadat H. 2012. A brief study of the prospect of solar energy in generation of electricity in Bangladesh. J. Selected Areas Renew. Sustain. Energy (JRSE); June Edition. Available from: http://citeseerx.ist.psu.edu/viewdoc/download?doi=10.1.1.389.6088\&rep=rep1\&type $=$ pdf

Sultana Z. 2001. Studies on the quality of true potato seeds obtained from different sources. a thesis of Master of Science in Horticulture. Department of Horticulture, Bangladesh Agricultural University, Mymensingh, Bangladesh.

Sukhatme S.P. 1997. Solar Energy: Principle of thermal collection and storage; Second edition. Tata McGraw-Hill Publishing Company Limited, New Delhi, India.

World Bank. 2016. Climate change knowledge portal. Available from: http://sdwebx.worldbank.org/ climateportal/index. $\mathrm{cfm}$ ?page $=$ downscaled_data_download\&menu $=$ historical 